\title{
Peer Group and Parental Support as Correlates of Academic Performance of Senior Secondary School Students in South West, Nigeria
}

\author{
Prof. Akomolafe, Comfort O. \\ Department of Educational Management, Ekiti State University, Ado-Ekiti \\ Dr. Mrs. Adesua, Veronica $O$. \\ Department of Curriculum Studies, \\ School of Education, College of Education, Ikere-Ekiti
}

doi: 10.19044/esj.2016.v12n7p306 URL:http://dx.doi.org/10.19044/esj.2016.v12n7p306

\begin{abstract}
This paper examines peer group and parental support as correlates of the academic performance of Senior Secondary School Students in South West Nigeria. The study adopted an ex-post facto design and descriptive research design of survey type. The population comprises all Senior Secondary School Students in South West Nigeria. The sample of the study consisted of one thousand, one hundred and fifty $(1,150)$ senior secondary school students (i.e. SS 3) drawn from three states out of the six states in the South West Geo-political zone; namely Osun, Ondo and Ekiti. The researcher made use of a questionnaire and an inventory to collect data. A self -designed questionnaire tagged "Motivation and Academic Performance of Senior Secondary School Students" (MAPSSS) was used to elicit information from the respondents. This consists of two parts. Parts A and B. Parts A consists of the bio-data of the respondents (students), while Parts B consists of 9 Sections, Sections A-I, Section $\mathrm{H}$ and I of the questionnaire support was used to measure the relationship between peer influence and parental support on students' academic performance. The two null hypotheses formulated were tested at 0.05 level of significance. The findings of the study revealed that there was a positive significant relationship between peer group, and parental support and the academic performance of students. On the basis of these findings, it was recommended that parents should monitor the type of peer group their children or ward mix or mingle with in school and provide the necessary support by providing all the educational needs of their children. They need to monitor the academic performance of their children/wards while they are in school.
\end{abstract}


Keywords: Academic performance, peer group, parental support, core subjects

\section{Introduction}

Students' academic performance has been receiving the attention of stakeholders in education. Education has been perceived to be expensive and been taken a significant portion of the nation resources whether budgeted or an intervention. Parents and peer groups have perceived to be significant in the social, psychological and educational development of the students. Contribution of parents have manifested not only of making provision school needs but making financial and psychological support for students both at home and in the school. A class consisting of groups of children can be described as peer group. It is pertinent to note that the child's peer group and the parents or home a child comes from, matter most in the life of a child. The influence of peer group pressure as well as the amount of parental support received from a child or individual learner has tremendous positive or negative impact to play in the academic well- being of a child.

Adesua (2014), explained that although, the school is a socializing agent that is responsible for the experiences that make up the individual's life, during school periods, the peer group a child mixes or grew up with and the parents of a child are two different sets or groups of socializing agents a child first comes into contact with. These groups are responsible for building the personality of the child and making the child what he becomes in life, their roles could make or mar the individual's (i.e. students) performances at school.

Longman Dictionary of contemporary English fifth Edition defines a peer as someone of the same age or social class while peer group refers to groups of people especially young of the same age or social group. Members in a peer group usually consist of people who are equal in age, education, social class, interest and background. The parent cum family is the first powerful agent of socialization or the first teacher a child comes into contact with, however as a child develops the next and most powerful agent of socialization.

Research has shown that positive correlation exists between performance and peer relationships. Kolawole (2004), is of the opinion that when adolescent student that are positively motivated do things in common during and after school hours such students' academic performance would be positively affected but if on the other hand, the groups major value is negatively related to academics, the individual's performance could be low. He further explained that while some students join peers that promote or pursue academic excellence, others join, interact with or promote peers from bad gangs or occult groups. Therefore the home as well as the school, has 
great role to play in promoting or checking peer group influence by including good programmes in the school curriculum as well as the extra curricular activities of the school to checkmate bad peer group influence.

Slavin (1987), Linney and Seidinann (1989), explained that there is a clear evidence that cooperative learning experiences, a situation in which students work together in groups rather than compete as individuals improve both academic performance and social interactions in children. In support of this, Diaz (2003), claimed that peer influence on the child's development occurs through similar mechanisms as those used by adult's reinforcement, modelling and direct teaching and skills. Interaction with peers also promotes acquisition, such as controlling aggressive impulses and the expression of pro-social behaviours.

Other research shows that positive correlation exists between performance and peer relationship. Casterjon and Perez (1998), explained that in relation to academic performance, the socio-metric status of the student influences performance both directly and indirectly, since it is influenced by intelligene.

Furlong, whipple, Jean, Simental, Seliz and Puthuna (2003), in a related study expressed that students' perceptions of connectedness to peers seems to impact significantly on school achievement. They examined the influence of peers on school engagement from three perspectives. Firstly, socio-emotional factors such as the quality of peer relationship, social competence and socially responsive behaviours impact on academic success.

In another dimension, Skues, Cunningham and Pokharel (2005), discovered that students who were bullied by their peer at school tended to report lower levels of self-esteem, feel less connected to peers, teachers and schools were less motivated to perform well at school.

A commonly used phrase that has the ring of substantial truth is that the parents are the first teacher of a child. Thus the home environment shape's a child's initial view about learning. Also there is another phrase, which says "charity begins at home", therefore the personality of a child's parents seems to affect a child's educational outcomes.

Over the years, reviewed literature indicated that there is an awareness of the importance of parental support on students academic performance. Ajila and Olutola (2007) were of the view that the home affects the individual since the parents are the first socializing agents in an individuals life. Early childhood philosophers like Rousseau, Pestalozzi, Froebel and Tagore are of the opinion that teaching is based on the nature of the child. Therefore, parental support could greatly influence the development of a child's motivational orientation.

Baumrind (1971), adduced that parenting styles helps a lot to shape a child's social competence. He described three categories of parents, these are 
Authoritarian, Permissive and Authoritative parents. He explained that authoritarian parents are autocratic, strict, rigid and children brought up under this type of parenting style tend to be unsocial, rebellious, dependent and withdrawn as well have poor academic performance. The permissive parents exhibit the laissez-faire parenting styles, there is so much laxity on the part of parents such that it involves inconsistent use of principles, children tends to have a low academic performance. The authoritative style, is however, democratic, it involves rearing children under moderate parent control, love, warm acceptance and respect for child's feeling. Such children tend to be friendly, independent and of high esteems and they perform better academcially than children from autocratic or permissive parents.

Ginsberg and Brostein (1993), explained that higher surveillance of homework, parental reactions to both good and bad grades were found to be related to an extrinsic motivational orientation and to higher performance. In a related study, Dembusch, Ritter, Leidemam, Roberts and Fraloigh (1987), found out that high school students with authoritative parents had higher grades in school than adolescents with either permissive or authoritarian parents.

Loeb, Horst and Horton (1980), are of the view that higher levels of overall parental involvement in the child's life have been found to be positively related to children's self-esteem, peer popularity and effective classroom functioning, school performance and teacher's ratings of competent behaviour. Specifically, children who perceived their parents as providing (support) encouragement tended to prefer challenges to easy tasks, were curious and interested in learning and solve problems on their own.

In another dimension, some researchers, however, are of the view that parents socio-economic status not just moral encouragement contributes to students' academic performance. There is the assumption that the social class or background a child comes from automatically affects the child's academic performance. Kayode (1999), is equally of the view that the family (parents') socio-economic status is a powerful predictor of academic achievement, because it predicts failure, truancy, suspension from school and school drop-outs. He further emphasized the need for parents to encourage and help parents to provide learning facilities, encourage children to read and show examples of intellectual activities through reading of newspapers magazines to have a wider vocabularly through which the child can benefit.

Danesy and Okediran (2002), lamented that the maternal and parternal deprivation of the essential need of young parents have prompted their poor performance in public examinations such as JSSCE, WASCE and NECO. In a related study, Johnson (1996), opined that poverty of parents has elastic effects on their children's academic works as they lack enough 
resources to sponsor their children, provide good schools, good housing facilities, medical care and social welfare services.

\section{Statement of the Problem}

It seems that the peer group students interact with either negatively or positively, motivate and influence them. It appears that when students get to school their minds tend to be like a "tabula rasa", but experience shows that when students mix with their peers, they tend to be greatly influenced. Reports from mass media show that students caught for anti-variance behaviour such as stealing, telling lies, examination mal-practices, sneaking out of school are those that seem to be influenced by their peers. Also, nowadays, it seems that some parents do not have enough time to monitor their children's academic activities. It was observed that the level of care given to children by their parents dictates the level of students' involvement in classroom activities. Experience has also shown that the influence of the family, such as parents' dynamic way of communication, effective relationship, attitude towards values, expectation and parenting style are capable of predicting performance and are very influential both in the students educational process as well as in family school relation.

\section{Purpose of the Study}

The purpose of this study is to examine peer group influence and parental support as correlates of the academic performance of senior secondary school students in South West Nigeria.

\section{Research Question} subjects?

What is the level of academic performance of students in core

\section{Research Hypotheses}

(i) There is no significant relationship between peer group influence and the academic performance of senior secondary school students.

(ii) There is no significant relationship between parental support and the academic performance of senior secondary school students.

\section{Methodology}

The research design for this study is an ex-post facto design and descriptive research design of survey type. It describes the relationship that exists between peer group, parental support and the academic performance of students. It involves the use of inventory to collect data (i.e. the certified true copy of the 2012 WAEC results of SS3 students). 
The population of the study consists of all senior secondary school students in South West Nigeria, which comprises Lagos, Osun, Ogun, Oyo and Ekiti State. The estimated population of public senior secondary schools as at the time of this study comprises 2,070 secondary schools in South West geo-political zone,

The sample for this study comprised one thousand, one hundred and fifty senior secondary school three students (i.e. SS3) from three states out of the six states in the South West geo-political zone. The sampled states are Osun, Ondo and Ekiti.

The validity of instrument was established with the help of experts in Educational Management, and Test, Measurement and Curriculum Studies. The reliability of the instrument was determined using test-re-test method and it yielded a coefficient of 0.85 .

Data were analysed using percentages for research question and Pearson product correlation method was used for hypotheses.

\section{Research Instrument}

The questionnaire and an inventory were employed to gather data. A self-designed questionnaire tagged "Motivation and Academic performance of Senior Secondary School Students" (MAPSSS) was used to elicit information from respondents on motivating factors that could enhance their academic performance. This consists of two parts: A and B. Part A is the bio-data of the respondents while Parts B consist of 9 Sections. Sections $\mathrm{H}$ and I on Peer Group Influence and Parental support was used to measure the impact of peer group influence and parental support on the academic performance of senior secondary school students.

\section{Data Analysis and Results}

\section{Research Question} subjects?

What is the level of academic performance of students in core

In determining the level of academic performance of students in core subjects, the results of students in 2012 West African Examination Council for the selected schools in the sampled states were obtained in core subject areas as depicted in Table 1. 
Table 1: Descriptive Analysis Showing the level of Academic performance of students on core subjects.

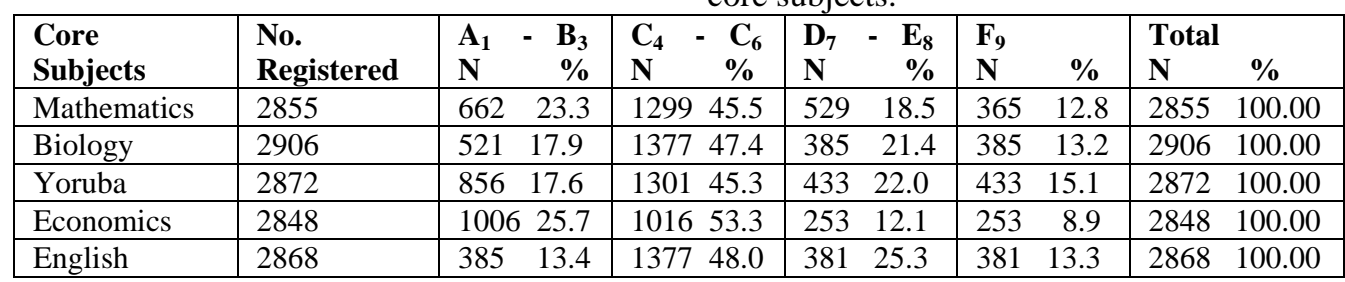

KEY

$$
\begin{array}{cl}
A_{1}-B_{3}= & \text { High level } \\
C_{4}-C_{6}= & \text { Moderate level } \\
D_{7}-E_{8} & =\text { Low level } \\
F_{9} & =\text { Failed }
\end{array}
$$

The level of academic performance during the period under review was relatively high as depicted in Table 1 above.

\section{Hypothesis 1}

There is no significant relationship between peer group influence and the academic performance of senior secondary school students.

The hypothesis was tested by correlating scores on peer influence with the weighted scores on the academic performance of senior secondary school students at 0.05 level of significance. The result is presented in Table

\begin{tabular}{|c|c|c|c|}
\hline Variable & $\mathbf{N}$ & r cal. & r table \\
\hline Peer Influence & 23 & \multirow[b]{2}{*}{$0.684 *$} & \multirow[b]{2}{*}{0.381} \\
\hline Academic Performance of Senior Secondary School Stu & 23 & & \\
\hline
\end{tabular}
2.

Table 2: Pearson Product Moment Correlation Summary of Peer Group Influence and the Academic Performance of Students.

$$
* \mathrm{P}<0.05 \text { (significant result) }
$$

Table 2 revealed that $\mathrm{r}$ cal $(0.684)$ was greater than $\mathrm{r}$ tab $(0.381)$ which was found at 0.05 level of significance. The null hypothesis was rejected. This implies that there was significant relationship between peer group influence and the academic performance of senior secondary school students. Hence, peer group influence had impact on the academic performance of senior secondary school students.

\section{Hypothesis 2}

There was no significant relationship between parental support and the academic performance of senior secondary school students.

In order to test the hypothesis, scores relating to parental support were correlated with the weighted scores on the academic performance of senior secondary school students was tested at 0.05 level of significance as indicated in Table 3. 
Table 3: Pearson Correlation Summary of Parental Support and the Academic Performance of Students

\begin{tabular}{|c|c|c|c|}
\hline Variable & N & r cal. & r table \\
\cline { 1 - 2 } Parental Support & 23 & \multirow{2}{*}{$0.480^{*}$} & \multirow{2}{*}{0.381} \\
\hline Academic Performance of Senior Secondary School Students & 23 & 0.38 \\
\hline
\end{tabular}

$* \mathrm{P}<0.05$ (significant result)

The null hypothesis was rejected $(\mathrm{r}=0.480, \mathrm{P}<0.05)$. This implied that there was significant relationship between parental support and the academic performance of senior secondary school students. Therefore, parental support had impact on the academic performance of students.

\section{Discussion}

The study indicated that there was significant relationship between peer group influence and the academic performance of students. This suggests that the group of students related with had positive impact on their academic performance. The findings supports that of Sprinthall and Collins (1994), Kolawole (2004) and Wentzel (1991), Furlong et al (2004), that students interaction with their peer group could influence learning and invariably their academic performance. The probable reason for this significant relationship is that, if students interact with the right peer group, that could positively influence their interest to learn, this could invariably motivate them towards their studies and enhance their academic performance. The result of this study contradicts that of Skues, Cunningham and Pokharel (2005), who discovered that students who were bullied by their peers at school tended to report lower levels of self-esteem, feel less connected to peers, teachers and schools were less motivated to perform well at school.

The study further revealed that there was a significant relationship between parental support and the academic performance of students. The findings support that of Olutola (2007), Baumrind (1980), Ginsburg and Brotein (1993), while it slightly contradicts the finding of Kayode (1999), Danesy and Okediran (2002) and Johnson (1996), that the family (parents) socio-economic status is a strong predictor of academic achievement not just the parenting styles and moral support encouragement received from parents' contributions to students' academic performance.

\section{Conclusion}

The peer group influence and parental support have been of great importance in the development of students. The study established that peer group influence has been of great relevance in students' activities and has resultant significant relationship with their academic performance. The role of parents in the positive development of students cannot be over 
emphasised, this statement has thus be ascertained with the positive relationship between parental support and students' academic performance.

\section{Recommendations}

Based on the findings of this study, it was recommended that parents should monitor the type of peer group their children mix with in school. They should ensure that their children or ward move with the right peer group. Also parents, regardless of their socio-economic status should provide the necessary support by providing all the educational needs of their children. They need to monitor the academic performance and general wellbeing of their children/wards while they are in school.

\section{References:}

Adesua, V.O. (2014). Motivation and Academic Performance of Senior Secondary School

Students in South West Nigeria. Unpublished Ph.D Thesis. Ekiti State University, Ado-Ekiti.

Ajila, C. and Olutola, A. (2001) in Uwaifo, V.O. (n.d.) The effects of Family Structure and Parenthood on the Academic Performance of Nigerian University Students Retrieved from the Internet. vuwaito@yahoo.com. June 2009.

Baumrind, D. (1971). Current Patterns of Parental Authority. Developmental Psychology Monographs 4 1-102.

Casterjon, J.L. and Perez, A.M. (1998). A Causal Explicative Model of Psycho-social Variables in Academic Performance. Revista Bordon. 50: (2), 171-185

Cunningham, E.G., Wang, W.C. and Bishop, N. (n.d.) Challenges to Student Engagement and School Effectiveness Indicators. Retrieved from the Internet. January 10, 2011.

Danesty, A.H. and Okediran (2002). "Ethilogical Factors and Effect of Street Working Behaviour Among Nigerian Youth" Journal of Social Problem School of Arts and Social Science F.C.E. (Specialist) Oyo . 2(1).

Dembusch, S.M; Ritter, P.L. Leidemam, PAR Roberts, D.F. and Fraleigh, M.J. (1987). The Relation of Parenting styles to Adolescent School Performance. Child Development. 58: 1244-1257.

Diaz, A.. (2003). "Personal, Family and Academic Factors Affecting Low Achievement in Secondary School”. Electronic Journal of Research in Educational Psychology and Psychopedagogy. 1: (i) P.P 43-66.

Furlong, M.J., whipple, A.P. Jean, G. Simential, J., Seliz, A. and Punthuna, S. (2003). Moving Towards a Unifying Framework for Educational Research and Practice. The California School Psychologist. 8:99-113. 
Ginsberg, G.S and Brostein, P. (1993). Family Factors to Intrinsic/Extrinsic Motivational Orientation and Academic Performance. Journal of Child Development. 65: (5) 1461-1471.

Johnson, J.O. (1996). Child Psychology. Wusen Press Limited. Calabar. Nigeria.

Kayode, B. (1999). Introduction to Sociology of Education. Lagos. Dedun Educational Books. P.O. 38-41/42.

Linney, J. And Seidinan F. (1989). The Future of Schooling. American Psychologist. 44:336-340.

Lieb, R.C., Horst, L. And Horton, P.J. (1980). Family Interaction Patterns Associated with Self-Esteem in Pre-Adolescent Girls and Boys. MerillPalmer Quarterly. 26: 203-217.

Longman Dictionary of Contemporary English. Fifth Edition. London. England.

Slavin, R.E. (1987). Developmental and Motivation Perspective on Cooperative Learning: A Reconciliation: Child Development. 58: 11611167. 